\title{
Socijalna integracija mladih u riziku od ispadanja iz sustava obrazovanja: rezultati slovenskog programa Projektno učenje mladih odraslih
}

MILOSLAV POŠTRAK*

Fakultet za socialno delo

Univerza v Ljubljani

Ljubljana, Slovenija

NATALIJA ŽALEC

Andragoški center Slovenije

Ljubljana, Slovenija
Izvorni znanstveni rad

UDK: 36: 371.212.8-053.6(497.4)

doi: $10.3935 /$ rsp.v27i3.1740

Primljeno: svibanj 2020.

\section{GORDANA BERC}

Studijski centar socijalnog rada

Pravni fakultet Sveučilišta u Zagrebu

Zagreb, Hrvatska

Za razumijevanje fenomena ispadanja učenika iz sustava obrazovanja važno je usmjeriti znanstveni i stručni interes prema shvaćanju životnog svijeta tih mladih iz njihove perspektive. U tu svrhu koristan je koncept socijalne ranjivosti mladih u kojem se istražuju čimbenici rizika u različitim životnim okolnostima mladih temeljem čega se razvijaju pristupi i programi usmjereni na preveniranje napuštanja obrazovanja, na rješavanje problema ispalih iz obrazovnog sustava i nezaposlenih mladih. Program Projektno učenje mladih odraslih (PUM-O) ujedinjuje oba pristupa i baziran je na razvijanju individualiziranog, holističkog $i$ strukturiranog načina rada s ranjivim mladima. Sastoji se od tri razine projektnih aktivnosti: izborne, individualne i interesne s ciljem razvijanja radnih navika, timskog rada, samopouzdanja i karijernih interesa radi reintegracije mladih u obrazovni sustav $i$ uključivanje na tržište rada i u društvo. Program je aktivan 25 godina u Republici Sloveniji u koji je uključeno preko 1370 mladih i financiran je sredstvima Europskog fonda za socijalni razvoj.

Ključne riječi: ranjivi mladi, ispadanje iz sustava obrazovanja, NEET populacija, projektno učenje mladih odraslih (PUM-O).

* Miloslav Poštrak, Fakultet za socialno delo, Univerza v Ljubljani / Faculty of Social Work, University of Ljubljana, Topniška ulica 31, 1000 Ljubljana, Slovenija / Slovenia, miloslav.postrak@fsd.uni-lj.si 


\section{UVOD}

Mladi koji nisu uspješno završili obrazovanje i koji nakon prekida osnovnoškolskog ili srednjoškolskog obrazovanja ne nastavljaju svoje školovanje i koji ne upisuju niti jedan oblik mogućeg nastavka obrazovanja su mladi koji su rano napustili obrazovanje (Ule, 2003.). Kada je riječ o mladima koji su pohađali i prekinuli srednju školu prije završetka predviđenog trogodišnjeg ili četverogodišnjeg programa, tada govorimo o prekidu obrazovanja mladih bez stjecanja svjedodžbe i bez stečene stručne kvalifikacije (Rumberger, 2011.), odnosno o mladima koji su ispali iz sustava redovnog obrazovanja (Strugar, 2011.; Berc, Majdak i Bežovan, 2015.). Ta činjenica ovim mladima na individualnoj razini daje slabe šanse u konkuriranju na tržištu radne snage, a na široj društvenoj razini predstavlja specifičan socijalni problem prvenstveno zbog teškoća njihove trajnije zapošljivosti (Berc, Majdak i Bežovan, 2015.). Iskustvo nezaposlenosti kod ovih mladih predviđa nestabilnu zapošljivost i u kasnijim godinama njihova života kao i lošiji socioekonomski status te se oni nerijetko suočavaju i s povećanim rizikom od socijalne isključenosti, siromaštva i zdravstvenih problema (Eurofond, 2012.). Dakle, ukoliko mladi nakon nezavršenog srednjoškolskog obrazovanja ostaju nezaposleni do 24. godine, oni ulaze u tzv. NEET populaciju (eng. not in employment, education or training) te predstavljaju posebno ranjivu skupinu, jer su izloženi rizicima trajnijeg nezapošljavanja, siromaštva, socijalne isključenosti, smanjene motivacije za ostvarivanje obitelji, pri čemu su žene zbog većeg udjela u toj populaciji više izložene ovim rizicima (Tomić, 2015.; Obadić, 2017.). Prosjek udjela ove populacije u zemljama članicama EU-a za 2016. iznosi oko 16\% (Eurostat, 2016., prema Obadić, 2017.), dok je 2018. taj udio porastao na $18,5 \%$ (Eurostat, 2019.). Podaci Eurostata za 2019. pokazuju prosjek od $10 \%$
NEET populacije pri čemu najviši postotak imaju Spanjolska i Malta (oko 17\%), a među zemljama s najmanjim udjelom NEET-a su Hrvatska (3\%) i Slovenija (5\%) (Eurostat, 2019.). Metodologija prikupljanja podataka o ovoj populaciji je posebna tema koja je za hrvatski kontekst nekoliko puta kritički elaborirana (Matković, 2010.; Berc, Majdak i Bežovan, 2015.), no možda vrijedi skrenuti pažnju da se registracija ove populacije uglavnom vodi pri zavodima za zapošljavanje, pri čemu je svega $57 \%$ ove populacije u EU registrirano pri zavodima koji obavljaju ovu djelatnost (Eurofond, 2016.).

Bez obzira na relativno niske stope NEET populacije u Republici Sloveniji i Hrvatskoj (prema navedenoj metodologiji praćenja) svaka mlada osoba ispala iz sustava obrazovanja zahtijeva pažnju obrazovnog i drugih pratećih sustava (poput sustava socijalne zaštite), zbog prethodno navedenih nepovoljnih posljedica koje NEET status donosi. U tom kontekstu postoje neke financijske procjene na razini Europske unije koje ukazuju na značajne materijalne iznose koji su usmjereni na podmirivanje troškova radi ublažavanja djelovanja različitih socijalnih, ekonomskih i zdravstvenih rizika, koje u prosjeku pripadnik NEET-a (oko jednog do dva milijuna eura po osobi) predstavlja za državu tijekom svog života (Europski parlament, 2011.).

Na osobnoj razini, iskustvo NEET statusa može se kod mlade osobe odraziti na njeno nezadovoljstvo životom, psihičko zdravlje, osjećaj manje vrijednosti i statusa u društvu, te ponekad potaknuti nekonstruktivne strategije ili načine života, ulazak u svijet ovisnosti i kriminala, čineći osobu manje produktivnom i socijalno uključivom što dugoročno smanjuje ukupni ljudski i socijalni kapital na društvenoj razini (Rumberger, 2011.).

Temeljem prethodno navedenog, može se reći da NEET populacija spada u skupinu ranjivih mladih ljudi. Ranjivost ove po- 
pulacije najčešće se očituje u tome što ona nema dovoljan sociokulturni kapital koji bi joj pomogao da izbjegne zamke i nepovoljne posljedice NEET statusa. Kako bi se osigurali uvjeti uključivanja tih mladih u obrazovne programe za aktivno participiranje na tržištu rada, država mora osigurati provedbu različitih mjera i reformi koje predstavljaju specifične programe dodatnog obrazovanja na nacionalnoj razini, a koje Europska komisija za svaku članicu Unije jasno propisuje u svom operativnom programu za učinkovite ljudske potencijale za razdoblje 2014.-2020. (Operativni plan - učinkoviti ljudski potencijali 2014.-2020.). Pametno planiranje socijalnih politika koje uključuje, između ostalog, i socijalno ulaganje u razvoj ljudskog kapitala društva nužno je od najranije dobi, te tijekom perioda obrazovanja i dalje, kako bi ih se pripremilo za suočavanje s rizicima, umjesto popravljanja posljedica osobnih i društvenih kriza koje su ih zahvatile (Hemerijck, 2017.). Uključivanje NEET populacije na tržište rada i smanjivanje stope ranog napuštanja školovanja mladih jedan je od glavnih ciljeva strategije Europa 2020. To je ujedno jedan od prioriteta za ulaganje Europskog socijalnog fonda, koji državama članicama stoji na raspolaganju za razvoj njihovih nacionalnih politika koje uključuju preventivne mjere, mjere intervencije i mjere usmjerene na vraćanje mladih u neki od oblika obrazovanja i pripremu za trajnije zapošljavanje (Europska komisija, 2013.).

Stoga je cilj ovog rada prikazati Program za učenje mladih - Odraslih (PUM-O) ${ }^{1}$ koji se u Republici Sloveniji provodi već dugi niz godina u okviru mjere 9.1.2. operativnog programa za provedbu europske kohezijske politike za razdoblje 2014.-2020., te se financira uz povjerenje i podršku Europskog socijalnog fonda (ZZalec, 2020.). Cilj rada je, osim toga, opisati PUM-O kao studiju slučaja u kojoj će biti analizirane metode rada $\mathrm{s}$ mladima, programski sadržaji i rezultati programa te ujedno pokazati uz koje resurse na nacionalnoj i lokalnoj razini, koordinaciju institucija i stručnih djelatnika je realizacija predviđenih mjera i inicijativa na razini strategije razvoja socijalnih politika Europa 2020 moguća kroz provedbu programa PUM-O.

PUM-O je program u koji se mogu uključiti mladi koji imaju iskustvo ispadanja iz škole i oni koji (još) nisu napustili školovanje, ali su neuspješni u obrazovnom procesu ili imaju poteškoće koje ometaju njihov dobar obrazovni ishod, pri čemu neuspjeh u učenju podrazumijeva i situaciju kada osoba subjektivno osjeća da postiže znatno manje nego što može, a ne samo u slučaju kad odustane od škole (Božič i sur., 2007.). PUM-O svoj profesionalni rad s mladima temelji na individualnom pristupu svakom članu grupe i uvažava njihov školski kontekst i obrazovni ishod. Osim toga, velika pažnja također se pridaje životnim okolnostima tih ranjivih mladih izvan školskih zbivanja, a koje bitno doprinose razumijevanju ukupnog životnog svijeta mladih i njihovim pozitivnim ishodima sudjelovanja u programu.

\section{ŽIVOTNI SVIJET RANJIVIH MLADIH IZVAN ŠKOLE}

Kako bismo imali cjelovitu sliku o razumijevanju razloga ispadanja učenika iz sustava obrazovanja i razloge njihova rizika od ispadanja, moramo razumjeti njihov cjelokupni životni kontekst, koji podrazumijeva značaj utjecaja različitih aspekata života mlade osobe izvan škole (Poštrak, 2007.a, 2015., 2011.a, 2011.b; Ule, 2008.; Šugman Bohinc i sur., 2007.). Razmatrajući značaj životnih okolnosti učenika izvan škole, autori recentne literature raspravljaju

\footnotetext{
${ }^{1}$ Detaljan prikaz koncepta PUM-O-a nalazi se na sljedećoj poveznici https://arhiv.acs.si/programi/ PUM-O.pdf.
} 
o čimbenicima koji su povezani s društveno neprihvatljivim oblicima ponašanja učenika (Ule i sur., 2000.; Šelih, 2000.), zatim o čimbenicima rizika (Wood i Hine, 2009.) i zaštitnim čimbenicima u okolini učenika (Čačinovič Vogrinčič, 2008.; Magajna i sur. 2008.).

Osim toga, stručnjaci koji neposredno rade u školi s učenicima naglašavaju da su od »neškolskih « razloga za ispadanje učenika značajni narušeni obiteljski odnosi, bolest jednog ili oba roditelja, socio-demografski pokazatelji poput obiteljskih prihoda i stambenih prilika, siromaštvo koje može pridonijeti socijalnoj isključenosti, zatim niža razina obrazovanja roditelja $i$ njihova motivacija da potiču svoje dijete na bolji uspjeh u obrazovanju (Berc, Majdak i Bežovan, 2015.). Navedeni čimbenici općenito se mogu nazvati čimbenicima odrastanja (Poštrak, 2015., 2011.a), pri čemu neki autori navode da u tom kontekstu vrijedi usmjeriti pažnju na spol učenika, obitelj s aspekta strukture i kvalitete odnosa, socijalnu sliku škole, dostupnost škole, utjecaj vršnjaka i vrijednosti mladih kao ključne čimbenike u odrastanju života adolescenata (Rumberger, 2011.; Baturina, Berc i Majdak, 2014.).

Razlozi ranog napuštanja srednjoškolskog obrazovanja najčešće su iznimno složeni jer dolazi do cirkularnog uvezivanja čitavog niza osobnih, okolinskih i institucionalnih čimbenika koji kroz vrijeme postaju izvor dugotrajnog i preplavljujućeg stresa za samog učenika i njegovu obitelj, pa je ispadanje učenika iz sustava obrazovanja mogući ishod takve situacije (Rumberger, 2011.).

U Sloveniji je krajem 1950-ih Katja Vodopivec (1959.) pisala o životnim uvjetima takozvane »delinkventne mladosti «. Smatrala je da maloljetnik može počiniti zločin iz nekoliko razloga, a najčešće zbog različitih pritisaka okoline koji su za adolescenta predstavljali preveliki teret ili iz želje da zadovolji svoje potrebe oslobađanjem emocionalne napetosti koja se razvila zbog frustracije, odnosno nemogućnosti nalaženja adekvatnog načina zadovoljavanja potreba (Skaberne, 1960.: 7, prema Poštrak, 1987.: 277). »Frustracija može nastati iz somatskih ili psiholoških nedosljednosti, koje mogu biti prirođene ili rezultat štetnih utjecaja u okolini, ili izravno uslijed loših uvjeta u kojima je maloljetnik živio.« (Skaberne 1960.: 8). U 1970-ima su autori upozoravali da »problem proizlazi iz samog djeteta, njegove obitelji, škole i društva u cjelini.« (Galeša, Gartner i Palir, 1972.: 75). Galeša i suradnici (1972.) ističu da u načinu reagiranja na frustraciju spol ima veliki značaj pri čemu »...dječaci reagiraju sasvim drugačije na frustraciju od djevojčica.« (Galeša, Gartner i Palir 1972.: 252). Gotovo identični čimbenici rizika od ispadanja iz sustava obrazovanja svrstani u četiri grupe istaknuti su mnogo godina kasnije: individualne karakteristike, obitelj, škola i zajednica (Whyte, 2009.; Baturina, Majdak i Berc, 2016.). Rumberger (2011.) uz sve navedeno dodaje i vremensku dimenziju i navodi kako je ispadanje učenika posljedica nastanka teškoća na više razina i vremenskog trajanja istih, naglašavajući da se najčešće radi o kontinuiranom djelovanju nepovoljnih čimbenika koji su vezani uz obrazovanje učenika, njegove obiteljske okolnosti, vršnjačku skupinu u školi i izvan nje. Kako bi se spriječio prekid školovanja, predložen je, između ostalog, »razvoj prikladnijih programa i metoda za obrazovanje nastavnog osoblja«, »osmišljavanje odgovarajućih programa i metoda rada $\mathrm{s}$ roditeljima«, »poboljšanje i povećanje broja ustanova koje se bave obrazovanjem i tjelesnim i mentalnim zdravljem predškolske djece« (Whyte, 2009.: 254-256). »Profesionalne službe trebale bi međusobno uskladiti svoje profesionalne koncepte i definirati te razgraničiti njihova područja rada $\mathrm{i}$ uloge te definirati odnose...«(Whyte, 2009.: 257). Rezultati suvremenih istraživanja pokazuju da se profesionalci koji rade s učenicima s 
teškoćama u učenju i dalje suočavaju s brojnim preprekama, a najčešće ističu one koje su vezane uz premalo suradničkog rada, premalo profesionalne podrške izvan institucije te nedovoljne vlastite kompetencije za pružanje adekvatne pomoći (Magajna i sur., 2008.).

Životni svijet (eng. life-world) adolescenta može biti ispunjen različitim otegotnim okolnostima koje prijete i mogu ga izložiti rizicima ranjivosti. Izraz »socijalna ranjivost « skovali su belgijski istraživači van Kerckvoorde, Vetterburg i Walgrave (1984., prema Ule, 2000.), kojim se opisuju pojedinci »...koji su u kontaktu s društvenim institucijama te su više izloženi kontroli i sankcijama nego koristima institucionalne intervencije« (prema Ule i sur., 2000.: 44). Ugroženim adolescentima nazivamo one koji su izloženi negativnim učincima čimbenika u svom životnom svijetu uz koje se ponekad može vezati pojam socijalne isključenosti. ${ }^{2}$ Unatoč nejasnoći izraza, on se koristi za označavanje nepovoljnog, marginaliziranog položaja pojedinih društvenih skupina, uključujući ranjive mlade. Pored toga, koristimo i izraz »mladi u društvu rizika i nesigurnosti« (Ule i sur., 2000.: 15).

Paneuropska anketa (Eurofond, 2012.) koju je provela međunarodna skupina stručnjaka pokazala je da u ranjiviju skupinu NEET-a pripadaju određene socijalne kategorije mladih. To su niže obrazovani mladi za koje je tri puta vjerojatnije od drugih skupina da će pripadati NEET-u, zatim mladi s imigrantskim podrijetlom za koje postoji $70 \%$ vjerojatnosti, bolesni i onesposobljeni mladi za koje postoji $40 \%$ vjerojatnosti za pridruživanje NEET-u te siromašni mladi za koje je $40 \%$ vjerojatnije i djeca razvedenih roditelja za koje je $30 \%$ vjerojatnije da će pripadati ovoj skupini. Ranjivost NEET populacije očituje se na više razina, jer imaju veću vjerojatnost da će biti nezaposleni, postati maloljetni roditelji, biti u sukobu sa zakonom, imati iskustvo zlouporabe droga i alkohola, biti lošijeg zdrava i u lošim odnosima u obitelji, što može generirati ove probleme i u sljedećoj generaciji (Eurofond, 2012.).

Životni svijet adolescenta je svakodnevni svijet u kojem on živi. U ovom se svijetu snalazi i razvija strategije života koje se temelje na osobnom iskustvu i iskustvu sa značajnim i uopćenim drugima (Mead, 1934.). Pojam »strategija ponašanja ili (ponovnog) življenja« odnosi se na sve one oblike, načine ili obrasce ponašanja, djelovanja, komunikacije koje je određena osoba razvila u svom dosadašnjem životu (Poštrak 2001.: 214-215). Ona razvija strategije života na temelju svojih ideja o stvarnosti. Svoje stavove stvara ili konstruira kroz objašnjenja simboličkog sadržaja koji su joj prenijeli drugi i koje je internalizirala. Simbolizirani sadržaji drugih su njene interpretacije i slike stvarnosti. Uobičajenu interpretaciju aktera u danom društvu Berger i Luckmann nazvali su društvenom konstrukcijom stvarnosti (Berger i Luckmann, 1989.). Na toj je osnovi Tomc (1992.) razvio diskurs o osobnoj konstrukciji stvarnosti, što je teorijsko polazište i u ovom radu. Dakle, glavna smjernica u profesionalnom radu s ranjivim mladima je razumjeti kakve strategije suočavanja s problemima koristi ranjivi adolescent, a koje je razvio na osnovi interpretacija vlastitih iskustava.

Tako se, primjerice, razlozi zbog kojih je adolescent odustao od školovanja nastoje objasniti razumijevanjem strategije ponašanja tog učenika u kontekstu njegovog

\footnotetext{
${ }^{2}$ Tanja Rener (2000.) ističe da je pojam socijalne isključenosti »Europska komisija unijela u europsku društveno-političku glasinu 1989. godine, oslanjajući se na francuski izraz iz 1974. godine i prvo ga je primijenila za ,skupine ljudi koje socijalno osiguranje ne pokriva“ «(Rener, 2000.: 116). Rener ističe da se u 1990-ima »pojam i njegova upotreba kao vatra proširila na politički korektan jezik europskih institucija i u profesionalne, posebno sociološke i socijalne, političke diskurse, a da se sam koncept uistinu ne analizira« (ibid.).
} 
životnog svijeta. U tom smislu, moguće je primijeniti koncepte G. H. Meada (1934., prema Poštrak, 1994., 2011.a), a i tumačenje razumijevanja tipa mladih kroz analitičke pojmove filistra, boema i kreativne osobe, kako ih opisuju Thomas i Znaniecki (1958., prema Poštrak, 2011.a). Adolescenti koji uđu u profil »filistra $\ll^{3}$ često se dobro snalaze u restriktivnijem školskom okruženju i lako prihvaćaju školska pravila. Osim toga, pod pojam filistra mogu ući mladi koji na životne situacije odgovaraju uglavnom bez sukoba i za koje Mirjana Ule (2003.) kaže da su »tihe« osobe koje se konformno suočavaju s realnošću te su svjesni gubitka globalne socijalne perspektive (Ule i sur., 2000.: 60-61). Među mladima koji napuštaju obrazovanje vjerojatno će se naći manje onih iz profila filistra, jer će mladi odustati od škole najčešće zbog subjektivnog osjećaja prevelike složenosti obrazovnog programa, a ne zbog sukoba s nastavnicima i slično.

U analitičkom pojmu boema, u prvom planu je osobni ili aktivni »ja«. Dijalog između osobnog i društvenog mišljenja nejasan je i kaotičan. Osoba ne poznaje pravila, ali čak i ako ih poznaje, ne poštuje ih i ne slijedi. Neki učitelji mogli bi definirati adolescente koji su bliski s ovom analitičkom kategorijom kao umjetničke osobe, opisujući ih na sljedeći način: »Tim mladim ljudima je dosadno na predavanjima, oni su svestraniji, rekao bih da su to umjetničke duše. Oni su umjetnički tipovi kojima škola uglavnom ne može osigurati dovoljno željenih aktivnosti.« (Grebenc, 2005.: 79). Granica između navedenih različitih analitičkih kategorija, koje ne sadrže vrijednosne prosudbe - zamagljena je i nejasna. Dakle, neki adolescenti koji bi se mogli klasificirati kao boemski vjerojatno su bliži definiranju tzv. kreativnih pojedinaca.

Analitički pojam kreativnih pojedinaca obuhvaća mlade koji uspostavljaju ravnotežu između osobnog i društvenog jastva, mišljenja. Dijalog je, dakle, kreativan. Osoba poznaje pravila, ali ih mijenja ako su neprimjerena ili nedjelotvorna. Pojam kreativnog pojedinca mogao bi se povezati s onim karakterističnim reakcijama mladih na različite životne situacije u suvremenom društvu, koje je Mirjana Ule (2008.) definirala kao odgovore mladih supkultura, a koje predstavljaju oblik jedinstvene ili čak »antistrukturalne« obrade stvarnosti. Ovi adolescenti mogu ironizirati stvarnost i preokrenuti je (Ule i sur., 2000.: 60-61).

$\mathrm{S}$ ovog gledišta, boemski tip strategije predstavlja privremeni izlazak iz svakodnevnog života u iluzornu zajednicu, što im pomaže da nekako probiju ostatak svog vremena (Ule i sur., 2000.: 60-61). Napuštanje školskog sustava i ulazak u drugu »iluzornu zajednicu « na ulici ili odustajanje od škole za njih postaje izlaz. Adolescenti koji bi se mogli smatrati kreativnim pojedincima također se mogu među njima naći, posebno ako postoji sukob između njih i rigoroznih, filistarskih aspekata određenog školskog okruženja ili pojedinih učitelja ili njihovog vodstva (Ule, 2003.).

\section{PODRŽAVAJUĆI STRUČNJACI KAO DIONICI DRUŠTVENIH RESURSA U STVARANJU POTENCIJALA KREATIVNOSTI RANJIVIH MLADIH}

Kako bi se upoznali resursi i rizici okruženja u kojem mlada osoba živi, važno je procijeniti moguće povoljne i nepovoljne

\footnotetext{
${ }^{3}$ Ovi autori koriste pojam filistra (philistine) koji osobe opisuje kao konformiste i za koje je društveno jastvo na prvom mjestu te koje znaju društvena pravila i prihvaćaju ih u potpunosti. Međutim, svaka važna i neočekivana promjena životnih uvjeta za te osobe rezultira dezorganizacijom aktivnosti, lošim rezultatima po kriterijima društva i same osobe, pa je osoba tada u »potpunosti izgubljena« i ne može zadržati kontinuitet obavljanja određenih aktivnosti (Thomas i Znaniecki, 1958.: 1854-1855).
} 
čimbenike formalnih i neformalnih izvora društvenih mreža (Miloševič i Poštrak, 2003.; Dragoš i Leskošek, 2003.). Razmatranje tih čimbenika najčešce se analizira u kontekstu makro- i mikrorazina iz perspektive Bronfenbrennerovog ekološkog modela (Vasta, Marshall i Miller, 2005.) te složenosti interakcija između obitelji, škole, zajednice i pojedinih institucija (Baturina, Berc i Majdak, 2014.). Analiza na makrorazini odnosi se na postojanje, kvalitetu i dostupnost različitih resursa na društvenoj i nacionalnoj razini. U ovu skupinu resursa uključene su mogućnosti školovanja, različiti obrazovni programi, nacionalni programi socijalne zaštite i drugi slični resursi kroz koje se između ostalog formira formalna društvena mreža institucija koja može pružiti oblike zaštite mladih od socijalne isključenosti (Košak, 2010.; Leskošek, 2010.; Simić, 2010.).

$\mathrm{Na}$ primjeru mladih koji su u riziku od ispadanja iz obrazovnog sustava može se vidjeti učinkovitost resursa na makrorazini umrežavanjem njegovih pojedinih dijelova - od školskog do sustava socijalne zaštite kojima bi se moglo »uhvatiti« ranjive i rizične mlade prije »pada $\ll$, tj. prije napuštanja škole ili barem započeti intenzivni profesionalni rad neposredno nakon napuštanja škole. $\mathrm{O}$ važnosti umreženosti institucija pisali su celjski istraživači već prije skoro pola stoljeća predlažući da bi stručne službe trebale međusobno »uskladiti svoje profesionalne koncepte te definirati i razgraničiti njihova polja rada i uloge te definirati svoje odnose ...«(Galeša, Gartner i Palir, 1972.: 257).

Dakle, radi se o povezivanju mreže resursa koja se može ispreplitati s neformalnim društvenim mrežama mladih, od njihovih obitelji do vršnjačkih skupina, odnosno do mikrorazine sustava pojedinog učenika. Analiza mikrorazine ekološkog modela mladih odnosi se na konkretne oblike rada $\mathrm{s}$ ranjivim mladima te stvaranja uvida o ka- rakteristikama njihova odrastanja. Razvoj strategija za svakodnevni život te emocionalne i socijalne vještine svrstavaju se u polje osobne kreativnosti koja je relevantna za određenu osobu, ali ne nužno i za društvo i iz perspektive društva.

U profesionalnom pomažućem radu s mladima kreativne metode predstavljaju osnovu za uspješan ishod, prvenstveno zato jer se u njihovom odrastanju želi potaknuti izražavanje osobnih potreba i interesa te razvoj sposobnosti za snalaženje u pojedinim situacijama. Stručna literatura naglašava da se u stručnom radu s ranjivim mladima polazi od postavke da je kreativnost u najširem smislu shvaćena kao vještina i sposobnost snalaženja u svakodnevnom životu. Margaret Boden razlikuje osobno ili psihološko (P) te povijesno ili društveno stvaralaštvo (D), pri čemu je psihološka kreativnost ona koju stvara određena osoba, a povijesna ili društvena kreativnost je ona ideja koju u povijesti nitko prije nije imao (Boden, 2004.).

U svakodnevnom životu često se zanemaruje osobna kreativnost jer je veća pažnja stavljena na aspekte društvene kreativnosti, budući da smo uglavnom fascinirani posebnim, velikim (umjetničkim ili znanstvenim) dostignućima (Poštrak, 1995.: 39). S aspekta pomažućeg rada s mladima, važno je sadržaje i metode rada usmjeriti na poticanje razvoja njihovih kapaciteta za osobnu kreativnost, kao što to pokazuje primjer rada PUM-O-a, pri čemu su bitni dostupni resursi u okolini mlade osobe uz pomoć kojih će ona moći učini nešto kreativno za sebe.

Iz perspektive pomagača, bilo da se radi o socijalnom radniku, savjetovatelju ili nastavniku koji je uključen u pomažući rad s ranjivim mladima u različitim socijalnim rizicima poput ispadanja iz sustava obrazovanja, može se reći da oni gube dodir s vlastitom kreativnošću. U tim situacijama njihovi su kapaciteti za učinkovito, samozaštitničko i kreativno suočavanje sa sva- 
kodnevnim izazovima i pritiscima bitno umanjeni te im tada često nedostaje unutarnja snaga, ali i vanjski resursi za stvaranje povoljnih ishoda problemske situacije, pa stoga oni sve više gube kontrolu nad vlastitim životom.

Kako bi se mladima vratila vjera u njihove unutarnje snage i stvaralačku kreativnost usmjerenu savladavanju problemske situacije, stručnjaci, osobito oni koji rade u školama u svom radu primjenjuju načela socijalnog kulturnog rada, odnosno društvenog ili savjetodavnog rada polazeći od potreba, želja i očekivanja mladih te od njihovog doživljaja vlastitog životnog svijeta da bi oni ponovno ovladali svojim životom i integrirali se u društvo (Poštrak, 2007.a). Pri tome stručnjaci u školi uključujući i socijalne radnike koji provode različite preventivne programe u školama, nastoje intervenirati u strukturiranje slobodnog vremena osobito ranjivih mladih, potičući kvalitetu sadržaja aktivnosti i razvoj potencijala mladih za suočavanje s nepovoljnim čimbenicima njihove uže socijalne mreže, od obitelji do vršnjaka (Poštrak, 2019.). Svrha tih aktivnosti i takvog pristupa je ublažavanje izloženosti tih mladih riziku socijalne nejednakosti, diskriminacije, marginalizacije, siromaštva te posljedicama narušenih i neprimjerenih međuljudskih odnosa u njihovoj mikrorazini ekološkog sustava (Poštrak, 2007.b; Berc i Buljevac, 2007.).

Kako bi učinci intervencija upućenih ranjivim mladima bili ostvarivi, potrebno je šire sagledavanje kapaciteta pojedinih resursa - organizacija i ustanova na makrorazini. U tom kontekstu, Belton (2010.) upozorava kako smo kolonizirali većinu ustanova od obrazovnih, zdravstvenih (vjerojatno i socijalnih) nudeći usluge tih institucija i istovremeno gurajući korisnike u »položaj ovisnosti, pasivnosti, apatije, kako političke tako i društvene« (Belton, 2010.: 7). Ovakva pozicija otvara brojna pitanja o potrebnom preoblikovanju uloga profesionalaca koji rade u zajednici, pri čemu se sugerira da se od »progonitelja« (Mrgole, 1999.) profesionalci izgrade u »poštujuće i odgovorne saveznike« (Čačinovič Vogrinčič i sur., 2005.: 8). Osim toga, Belton tvrdi da naše korisnike trebamo »...gledati kao ljude pune potencijala koji nas mogu poučiti o sebi, baš kao što ih mi možemo poučavati o nama« (Belton, 2010.: 91).

$\mathrm{Na}$ istom tragu, neki suvremeni autori pišući o savjetovanju kao metodi pomaganja naglašavaju važnost prepoznavanja osobnih kapaciteta korisnika i osjetljivost savjetovatelja na potrebe i doživljaj osobe o vlastitoj problemskoj situaciji, stavljajući osobu u središte procesa stvaranja pozitivnih promjena i kvalitete života (Mearns i Thorne, 2007.; Hackney, 2012.).

$\mathrm{O}$ važnosti individualnog pristupa $u$ savjetovanju je još 1995. pisala Azra Kristančič, ističući da »Poštovanje stvara kreativniji i zadovoljavajući recipročni odnos. Poštujući klijentovu osobnost, pomažemo mu da prihvati sebe kao osobu koja raste $\mathrm{i}$ razvija se i stječe nove sposobnosti i načine kako se snalaziti u stvarnosti svakodnevnog života. Poštovanje osobe u savjetodavnom odnosu savjetovatelj pokazuje na takav način da ne prijeti sugovorniku, ne kritizira ga ili ne prosuđuje o ispravnosti ili netočnosti njegovih procjena i normi.« (Kristančič 1995.: 11). Naslanjajući se na ove postavke odnosa prema korisnicima, formiraju se principi komuniciranja s mladima, pri čemu je važno mladima pokazati već spomenuto poštovanje, podršku, povjerenje u njihove resurse, ali i prihvaćanje njih upravo onakvima kakvi su, umjesto moraliziranja, kritiziranja, zapovijedanja, podučavanja (Gordon, 1983.), umjesto odbijajućih stavova i ponašanja stručnih djelatnika na koje upozoravaju Flaker i suradnici (2005.).

Vezano uz podržavajuće ponašanje prema mladima, Thomas Gordon (1983.) kao rješenje nudi »jezik prihvaćanja«, tumačeći 
da je to temelj komunikacije s osobom kojoj potvrđujemo ono što ona jest i što joj »omogućava da se razvija i konstruktivno rješava probleme.« (Gordon, 1983.: 44).

Slično tome, Glasser govori o oblicima komuniciranja koji blokiraju ili poboljšavaju komunikaciju (Glasser 2002.: 19), pa navodi ubojite navike poput kritiziranja, optuživanja, kažnjavanja, prigovaranja, prijetnji, jadikovanja i potkupljivanja. Nasuprot tome, autor nudi sedam navika koje se stječu marljivošću, povjerenjem, slušanjem, podrškom, doprinosom, prijateljstvom, poticanjem, a koje su iznimno važne za konstruktivan rad s mladima i koje se tijekom poticajnih aktivnosti mogu razviti u radu s mladom osobom (Glasser, 2002.). Upravo takve teorijske spoznaje govore u prilog temeljnih postulata profesije pomagača u radu s mladima, a koji treba imati kompetencije poštujućeg i odgovornog pomagača-saveznika i koji ima vještine korištenja jezika prihvaćanja i ohrabrenja te poticanja razvoja povjerenja, podrške, samopoštovanja i samopouzdanja kod mlade osobe.

Profesionalci bi trebali moći slušati što mladi ljudi imaju reći o svom životu, shvatiti njihovu ideju o svijetu ozbiljno i stvarno. Iz svoje perspektive, mladi su najkompetentniji reći nešto o sebi, svojim osjećajima, ponašanju, strahovima i nadama. Iako neki postupci i oblici ponašanja nisu uvijek prikladni za njih i za druge, mladi su »stručnjaci iz svakodnevnog iskustva « pa su ujedno aktivni sudionici $u$ procesu rješavanja vlastitog problema (Čačinovič Vogrinčič, 2008.; Poštrak, 2015.). Socijalni radnici i drugi predstavnici pomagačkih profesija koji su uključeni u planiranje i izvedbu tretmanskog i preventivnog rada s ranjivim mladima, kao što je to primjer PUM-O-a, zajedno s mladima stvaraju rješenja, svaki sa svojom odgovornošću i svaki sa svojim autoritetom što ih dovodi do realizacije željenih ciljeva i rezultata.

\section{PROJEKTNO UČENJE MLADIH ODRASLIH (PUM-O): MULTIDISCIPLINARNI PRISTUP RANJIVIM MLADIMA ZA AKTIVIRANJE NJIHOVIH OSOBNIH POTENCIJALA I SOCIJALNU INTEGRACIJU}

Projekt učenja mladih odraslih u Sloveniji počeo se formirati krajem 1992. u Andragoškom centru Slovenije (ACS) pod radnim nazivom Center za mlajše odrasle (Centar za mlade odrasle). U svrhu provedbe projektnih aktivnosti ACS je već od samih početaka rada projekta surađivao s nekoliko važnih dionika, a to su prije svega Zavod za zapošljavanje, Ministarstvo za obrazovanje, znanost i šport, Ministarstvo rada, obitelji, socijalne skrbi i jednakih mogućnosti. Nositelji i izvršitelji programa obrazovanja za mlade odrasle bili su stručnjaci različitih profila (psiholozi, pedagozi, socijalni radnici, inženjeri, ekonomisti, povjesničari, lingvisti, dizajneri, slikari, glazbenici).

PUM-O je jedan od prvih razvojno važnih zadataka na polju obrazovanja odraslih u neovisnoj državi Sloveniji. Najvažniji razlog zbog kojeg je država Slovenija prepoznala obrazovanje mladih odraslih kao prioritetno i razvojno pitanje je podatak koji pokazuje da je u Sloveniji ranih devedesetih godina u kvoti nezaposlenih osoba udio mladih bez osnovnog zanimanja bio u bitnom porastu tijekom tranzicije s planirane na tržišnu ekonomiju i koji je nastao kao posljedica te tranzicije. Naime, 1992. godine tražitelji posla mlađi od 25 godina činili su $36,3 \%$ svih nezaposlenih što je iznosilo gotovo 43000 osoba. Od tog broja nezaposlenih mladih, $42 \%$ njih ili gotovo 16000 je bilo bez završenog nekog oblika srednjoškolskog obrazovanja, odnosno bez strukovne škole ili gimnazije (Žalec, 1994.). Osim toga, početkom 1990-ih, u Sloveniji je zabilježeno više od $20 \%$ prekida srednjoškolskog obrazovanja, kako su pokaza- 
le dvije uzastopne longitudinalne studije u kojima je grupa savjetnika za karijeru pri Zavodu za zapošljavanje pratila pet godina čitavu generaciju upisanih u četverogodišnji srednjoškolski program (Žalec, 1994.). Naime, prvotna metodologija praćenja napuštanja obrazovanja temeljila se na longitudinalnom praćenju učenika ispalih iz sustava obrazovanja, koje je uzelo u obzir svaki pojedinačni slučaj odustajanja od srednjoškolskog programa, odnosno pratilo se učenika koji nije završio srednju školu u propisanom roku, tj. unutar $4+1$ godine nakon upisa.

Danas se u metodologiji praćenja ispadača koriste zbirni podaci dobiveni iz Ankete o radnoj snazi, koja udovoljava kriterijima EUROSTAT-a pri čemu je definicija ranog napuštanja školovanja (ZOIU) identična definiciji ELET-a kako je koristi Eurostat. Drugim riječima, radi se o udjelu ukupne populacije u dobi od 18 do 24 godine s razinom obrazovanja ISCED 2 koja obuhvaća završenu ili nezavršenu osnovnu školu ili nezavršeno srednjoškolsko obrazovanje te mlade koji nisu bili uključeni u bilo koji oblik (formalnog ili neformalnog) učenja tijekom četiri tjedna prije ispunjavanja ankete.

Ovdje je vrijedno još dodati podatak da je početkom 90-ih godina, prema podacima Statističkog ureda Republike Slovenije, zabilježeno između 5 i $8 \%$ učenika koji nisu uspješno završili osnovnu školu ili koji nisu nastavili školovanje po završetku osnovne škole (Žalec, 1993.). Šanse tih mladih koji su se tada našli na tržištu rada nisu bile obećavajuće, jer su bili bez potrebnog stupnja obrazovanja, strukovnog usmjerenja, bez radnog iskustva, ali i bez prave sustavne podrške koja bi im pomogla da prebrode svoj težak socijalni status. Situaciju mladih koji napuštaju tržište rada pogoršala je u to vrijeme i stigmatizacija tih mladih s predrasudama da se radi o razmaženim mladim ljudima, mladima koji su lijeni ili se ne trude dovoljno ili su manje intelektualno sposobni od svojih vršnjaka.

Danas se stopa napuštanja srednjoškolskog obrazovanja u Sloveniji procjenjuje na manje od 5\%, a mladi u dobi od 15 do 29 godina su u prosincu 2019. godine činili udio od 20,1\% ili nešto više od 15000 ljudi u strukturi populacije nezaposlenih, što uključuje sve obrazovne kategorije mladih (ZRSZ, 2019.). Smanjenje stope nezaposlenosti mladih, između ostalog, može se pripisati programima aktivne politike zapošljavanja (ESS), koji integriraju različite programe obrazovanja i osposobljavanja u kojima mladi mogu sudjelovati, uključujući i program PUM-O (Delloite, 2019.).

S druge strane, smanjena stopa prekida školovanja pripisuje se mjerama koje omogućuju mladima da se više puta upišu u iste ili različite obrazovne programe, uključujući one usmjerene posebno na odrasle. Uz ove ohrabrujuće podatke o smanjenju stope ispadanja učenika iz sustava obrazovanja, treba dodati odgovarajući stupanj kritičnosti prema definiciji napuštanja škole, koja uzima u obzir samo one učenike koji su napustili školovanje bez završetka obrazovanja i tek donekle pokriva i drugi školski neuspjeh - njegove uzroke i posljedice za mlade. To se uglavnom odnosi na one mlade ljude koji su više puta upisani u različite obrazovne programe, ali ne mogu ih završiti jer se suočavaju s raznim preprekama u životu i često se upisuju kako bi stekli status učenika što im donosi mogućnost korištenja određenih prava važnih za njihovu egzistenciju (prijava za prikladan posao i slično). Istovremeno, škole nastoje zadržati većinu učenika, a istovremeno nemaju odgovarajuće strategije za pomoć mladim ljudima koji su pogođenim ranim napuštanjem škole kako bi uspjeli u školi (Knavs i sur., 2019.).

Nizak udio ispadača zabilježen na nacionalnoj razini (ispod 5\%) povećava rizik da se zanemaruju problemi učenika koji ne uspijevaju u izvršavanju školskih obveza 
iz razloga koji nisu vezani za školu. Naime, kada je riječ o malom udjelu neke pojave (pr. ispod $10 \%$ ), poput ispadanja iz obrazovanja, to se ne smatra izazovom u nadležnom političkom rakursu, niti su razlozi za to traženi. Udio od deset posto smatra se normalnom pojavom koja zanemaruje druge čimbenike koji mogu biti u kompetenciji drugih područja politike koja su vrlo važna za nizak školski uspjeh i nepovoljan ishod učenika, poput prekida školovanja. Primjerice, rizici poput siromaštva, imigracije, etničke pripadnosti, posebnih potreba učenika predstavljaju čimbenike koji nisu usko vezani uz školske uvjete, ali imaju snažan utjecaj na obrazovni ishod učenika i njegovu dalju budućnost. Zanemarivanjem ovih čimbenika i onih na razini škola i obrazovnog sustava stvara se i produbljuje segregacija u društvu, što može imati dugoročne posljedice za obespravljene kao i za cjelokupni društveni sustav. Program PUM-O namijenjen je i učenicima koji su izloženi prethodno navedenim rizicima, jer u suradnji s učenikom, njegovim roditeljima, školom i stručnjacima PUM-O-a može se kreirati individualni obrazovni plan koji omogućava učeniku da uz pomoć programskih aktivnosti ublaži ili riješi ove probleme.

Dakle, program PUM-O usmjeren je ne samo na učenike s iskustvom ispadanja iz sustava obrazovanja nego i na učenike u riziku od ispadanja, a s ciljem osnaživanja njihovih osobnih potencijala te integriranja u obrazovne programe i tržište rada te predstavlja odgovor na socijalni problem ispadanja učenika iz sustava obrazovanja i njegove posljedice. Prethodno naveden kratki pregled razvoja programa pokazuje da rješenja koja nudi program zbog svoje inovativnosti i raznolikosti, iziskuju nekoliko godina kontinuiranog rada kako bi se postigli odgovarajući rezultati u praksi (Delloite, 2019.).

Tadašnje škole, iz razdoblja ranih devedesetih godina, koje se još nisu suočile s demografskim učincima generacija koje ispadaju iz sustava obrazovanja i konku- rencijom u svom području obrazovnih programa, nisu poduzele posebne mjere $\mathrm{i}$ provele programe s tim mladima koji napuštaju obrazovanje kako bi ih zadržali u školi. Osim toga, porastu ranog napuštanja srednjoškolskog obrazovanja pridonijela su i pravila škole prema kojima učenici koji nisu uspjeli dva puta s pozitivnom ocjenom završiti pojedini razred, nisu mogli nastaviti školovanje. Mladi koji su u tim okolnostima ispali iz sustava obrazovanja pokazuju da su razlozi za njihov školski neuspjeh povezani s nedostatkom motivacije za obrazovanje, jer su se, zbog ograničene kvote upisa u srednje škole, upisivali u obrazovni program za koji nisu bili zainteresirani (Mrgole i ̌̌alec, 1996.a). Drugi razlog njihova ispadanja iz sustava obrazovanja bile su poteškoće u njihovoj prilagodbi novim školskim zahtjevima u prijelazu s osnovnog na srednjoškolsko obrazovanje. U tom kontekstu, najveće stope prekida srednjoškolskog obrazovanja zabilježene su u prvoj godini - oko $16 \%$ od čega je 7,5\% učenika odustalo nakon prvog neuspjeha (Žalec, 1993.). Razlozi neuspjeha koje su mladi naveli bili su očekivani, jer nisu dobili pomoć za rješavanje svojih obrazovnih problema unutar sustava obrazovanja, iako su, kako pokazuje višegodišnji rad u okviru PUM-O programa, razlozi obrazovnog neuspjeha složeniji i proizlaze iz njihove životne situacije.

Prekidu obrazovanja doprinose također narušeni i nasilni odnosi među vršnjacima u razredu. Tako, primjerice, polaznici PUMO-a u programu osnovne škole za odrasle često izjavljuju da su se tijekom školovanja osjećali izolirano i usamljeno, što je rezultiralo osjećajem isključenosti. Socijalna klima u školi i međuljudski odnosi rijetko su tema rasprava u razredu i ne pridaje im se konkretna i dublja pažnja važna za razumijevanje odnosa mladih i njihova pitanja i dileme. Iz tih razloga mladi nemaju prilike učiti o međuljudskim odnosima te o načinima kako kontrolirati ponašanje, emocije i 
riječi. Školski pravilnik koji definira pravila ponašanja učenika u održavanju školskog reda su pravila koja se reguliraju kroz prekršaje i predviđene kazne, a prema percepciji polaznika PUM-O-a, trebala bi se provoditi kroz stimulacije, upute i primjere, koji bi potaknuli dobre međuljudske odnose.

Evaluacija Osnovne škole za odrasle koja uključuje korisnike različitih dobnih skupina koji su odustali od školovanja, pokazala je da polaznici programa nisu imali adekvatan socijalni i kulturni kapital koji bi im omogućio uspješno završavanje osnovnog obrazovanja tijekom redovnog školovanja (Žalec, 2016.). S druge strane, nastavnici i stručni djelatnici škole svoju uloge u manjem broju vide u odgovornosti za promicanje dobrih međuljudskih odnosa, već se identificiraju sa sadržajem predmeta koji se uči, što umanjuje mogućnost korištenja još jednog potencijalnog izvora podrške ranjivim mladim ljudima.

Nasuprot tome, pristup polaznicima u PUM-O programu je potpuno drugačiji, jer se temelji na načelima individualiziranog pristupa, a dobri međuljudski odnosi i briga članova jednih o drugima ključni su čimbenici uspjeha programa. Mentori grupa su posebno educirani za vođenje i usmjeravanje grupne dinamike, pa se o grupnim procesima i dobrobiti svakog sudionika u grupi vodi osobita briga. Program kao takav je upečatljiv primjer nastavnog plana $\mathrm{i}$ programa za razvoj procesa koji se temelji na snazi pojedinca i njegovoj povezanosti s članovima grupe. Kad se tijekom programskih aktivnosti zadovolji potreba pojedinca za prihvaćanjem od strane grupe i kada se stvore uvjeti da pojedinac može izraziti svoju kreativnost i doprinijeti zajednici, tada dolazi i do pozitivne promjene u pojedincu u odnosu na samog sebe i na okolinu. Takva promjena osobne perspektive i osnaživanje osobnih potencijala omogućava pojedincu aktivno rješavanje problema koje je prethodno izbjegavao ili zbog kojih je odgađao donošenje potrebnih odluka i aktivnosti uz prihvaćanje odgovornosti.

Stoga se može reći da su ukupni ishodi PUM-O programa za ranjive mlade sudionike programa bitno povezani s učincima izvjesnog sociokulturnog kapitala koji polaznik stekne sudjelujući u programu.

Budući da je cilj programa kvalitetna i procesna priprema nezaposlenih mladih (u dobi 15-26 godina) za njihovu uspješnu reintegraciju u društvo kroz ponovni ulazak u obrazovni sustav ili kroz ulazak na tržište rada, važna je briga o održivosti provedbe samog programa. U tom smislu, valja istaknuti da se program PUM-O provodi kao dio aktivne nacionalne politike zapošljavanja, odnosno u okviru mjera osposobljavanja i obrazovanja. On se financira iz sredstava Europskog socijalnog fonda u okviru devete prioritetne osi: socijalna uključenost i smanjenje siromaštva, 9.1 prioritetno ulaganje: aktivno uključivanje, uključujući promicanje jednakih mogućnosti i aktivno sudjelovanje i poboljšanje zapošljivosti, poseban cilj 9.1.2 osnaživanje ciljnih skupina za približavanje tržištu rada Operativnog programa za provedbu, Europska kohezijska politika za razdoblje 2014.-2020. ${ }^{4}$.

\footnotetext{
${ }^{4}$ Operativni program-učinkoviti ljudski potencijali 2014.-2020. jasno navodi da se Hrvatska obvezuje u cijelosti provoditi Plan implementacije Garancije za mlade (PIGzM), u sklopu svojih investicijskih prioriteta (oznaka 8ii). Zanimljiv je podatak da su sredstva ESF-a trebala biti usmjerena na jačanje tržišta rada, organizacije civilnog društva, socijalnih partnera i komornih udruženja radi stvaranja uvjeta rada s mladima koji su ispali iz sustava obrazovanja i NEET populacijom, no podaci sustavne evaluacije tih realiziranih zahtjeva su izostali. Vrijedi spomenuti da se ovim problemom u Hrvatskoj aktivno bave organizacije civilnog društva, poput Pragme koja svojim programima obuhvaća rad s mladima u riziku od ispadanja iz obrazovanja i CERANEO koji je 2012. proveo istraživačke projekte »Podrška mladima u obrazovanju: analiza socijalnih rizika koji doprinose napuštanju srednjih škola u gradu Zagrebu « 2012.»Reaktivacija i integracija marginaliziranih mladih - NEET na tržište rada-RIM « koji je proveden 2018., a sufinanciran je sredstvima Europskog socijalnog fonda (https://ceraneo.hr).
} 
U svrhu praćenja učinkovitosti programa vrši se redovita evaluacija programa još od samih početaka programa, pri čemu se provjerava njegova svrhovitost iz perspektive sudionika programa, zatim se ocjenjuje relevantnost odabranog sadržaja, postignuta harmonija između različitih projekata $\mathrm{i}$ dionika te povezanosti programa PUM-O i resursa lokalne zajednice (Delloite, 2019.).

Za praćenje programa i njegovo ažuriranje izrađena je posebna dokumentacija koja je omogućila praćenje pojedinca (osobni plan obrazovanja), planiranje i vrednovanje izbornog projektnog rada i praćenje provedbe programa na razini provedbene organizacije (godišnje izvješće). Podaci iz osobnog obrazovnog nacrta, odnosno plana, osnova su izvještaja koje izvođač/mentor priprema svake godine. Iz godišnjih izvještaja izvođača programskih aktivnosti svih grupa PUM-O koje se izvode u Republici Sloveniji kreira se nacionalno izvješće, koje ocrtava trendove i potrebe sudionika, kao i potrebe mentora te se iskazuju neke sistemske prepreke. Na ljetnim susretima diskutiraju se nalazi izvođača programa, fondova $\mathrm{i}$ Andragoškog centra Slovenije te se pokušavaju naći odgovarajuća rješenja. Povrh toga, provedene su i vanjske evaluacije programa od čega prva 2002., druga 2010. godine, a posljednja 2018. godine (Andragoški center Slovenije 2010.; Delloite, 2019.). Na temelju nalaza evaluacije, Andragoški centar Slovenije nadopunjuje kurikul programa, a posljednje konceptualno ažuriranje izvršeno je 2016. godine, nakon čega su do 2020. slijedila manja ažuriranja koja su bila vezana uz tjedno trajanje programa i slično.

\section{Povezivanje ciljeva obrazovanja i socijalne integracije}

Program PUM-O sastoji se od tri ključne aktivnosti: 1) izborni projekti, 2.) individualni rad na projektu 3.) interesne aktivnosti.

1) Izborni projekti predstavljaju različite aktivnosti koje kod sudionika potiču stvaranje radnih vještina $\mathrm{i}$ iskustvo timskog rada i mogu trajati nekoliko tjedana do nekoliko mjeseci. To su, primjerice aktivnosti uređivanja i pripreme PUM-O časopisa, uređenja vrta u dvorištu, preuređivanja prostora u kojem grupa radi, snimanje kratkih filmova, priprema lutkarskih predstava i slično, ovisno o izboru sudionika programa. Kada se zamišljena ideja uz pomoć mentora privede kraju, odnosno kad je projekt završen, on se predstavlja javnosti. Tako se, na primjer, aktivnosti programa (predstava, video produkcija i slično) prikazuju u dvorani Centra urbane kulture Kino Šiška u Ljubljani, na javnoj pozornici ili na mrežnim stranicama programa. Prikazivanje filma »Želim živjeti«, koji je rezultat jednog PUM-O projekta, prikazan je nekoliko puta $\mathrm{u}$ javnosti i dospio je u stručnu, političku i opću javnost. Za PUM-O projekte je nužno zakoračiti u širi prostor i na taj način osvijestiti opću javnost o problemima mladih koji se bore s izazovima nastavka obrazovanja i zapošljavanja te o postojanju tog problema u društvu, a ujedno na taj način omogućiti mladima da jačaju svoje kompetencije aktivnog građanstva i samoinicijative.

2) Pojedinačni projektni rad uglavnom uključuje radionice koje bi trebale poboljšati šanse pojedinca za daljnje zapošljavanje ili (ponovno) uključivanje u obrazovanje. Primjeri takvih pojedinačnih projekata su učenje slovenskog jezika, učenje stranih jezika, radionice za posao, individualne pripreme za razgovor za posao, radionice o nastavnim tehnikama, pisanje životopisa. Kroz pojedinačne radionice polaznici bi trebali razviti ili poboljšati samoinicijativnost i sposobnost cjeloživotnog učenja, što se vrednuje kao jedna od glavnih kompetencija koje pojedinac može steći tijekom sudjelovanja u ovom programu. 
3) Interesne aktivnosti imaju za cilj proširenje interesa pojedinca, koji su kod njih vrlo uski ili slabo razvijeni. Uz ovaj, cilj je interesnih aktivnosti i stjecanje općih znanja i razvijanje vještina za socijalnu uključenost pojedinaca. Često iz interesne aktivnosti iznikne ideja za izborni projekt $t^{5}$. U sklopu ovih aktivnosti mentori s polaznicima grupa obrađuju teme vezane uz razvoj zdravog načina života, zatim uz načela održivog razvoja i ponovne uporabe nekih materijala i predmeta, uz razvijanje grupne dinamike, istraživanje lokalnog okoliša i slično. U ovu skupinu aktivnosti spadaju i neizostavni »razgovori uz kavu« i različita grupna okupljanja sudionika. Sudjelovanjem u sličnim radionicama sudionici programa dijele svoje osjećaje $\mathrm{i}$ iskustva te se tako povezuju s ostalim članovima grupe i sklapaju prijateljstva (Delloite, 2019.).

Iako je program PUM-O u osnovi obrazovni program zasnovan na individualnom andragoškom tretmanu, čak se pri evaluaciji pilot projekta pokazalo da uspjeh programa uvelike ovisi o upravljanju dinamikom grupe za učenje i njenog rada, pri čemu se mentori za rad s tim grupama moraju stručno pripremati. Potrebe sudionika programa su vrlo raznolike i često šire od obrazovnih. One se najčešće odnose na osnovne psihološke potrebe za sigurnošću i prihvaćanjem, poštovanjem i samopoštovanjem, a neki sudionici imaju i osnovne egzistencijalne potrebe, posebno oni koji postaju beskućnici (Mrgole, Žalec, 1996.a,b,c). Naknadne studije pokazale su da su polaznici programa vjerojatno žrtve velikog stresa i traumatičnih događaja koje uzrokuju njihovi bliski članovi obitelji (roditelji, rodbina, partneri, poznanici) i povezani su s fizičkim, psihičkim i seksualnim nasiljem (Guzelj, 2012.). U takvim životnim okolnostima očekivano je da se obrazovne ambicije kod mlade osobe svedu na minimum $\mathrm{i} u$ konačnici ugase $\mathrm{u}$ potpunosti, a njihovi osobni potencijali se nerijetko svode na ispunjavanje osnovnih životnih funkcija, pa ih Guzelj (2012.) naziva »preživjelima«.

Neuspjeh ranjivih mladih u školi je stoga pokazatelj i posljedica nagomilanih problema koje adolescent ne može riješiti sam. Topla i inkluzivna socijalna klima u PUM-O pomaže sudionicima programa da prebrode svoju trenutnu situaciju. Ključni elementi, koji su nakon pažljivog razmatranja dodani početnom planu programa, bili su primarno povezani s organizacijom i provedbom najznačajnijih aktivnosti koje potiču kohezivnost grupe za učenje i to ne samo s uključivanjem sudionika u program, već i svakodnevno kroz aktivnosti koje nisu vezane za učenje za posao, nego kreativne aktivnosti za poticanje njihovog samopouzdanja i samopoštovanja. Sudionici programa uključeni su u jasnu strukturu dnevnih i tjednih obveza što im daje osjećaj sigurnosti, pripadanja i mjerljive učinkovitosti na osobnoj i grupnoj razini (Mrgole i Žalec, 1996.a,b,c).

Poseban značaj u programu posvećuje se međuljudskim odnosima u grupi koji se temelje na ekvivalentnosti sudionika, međusobnom poštovanju, povjerenju i grupnoj pripadnosti. Kako bi se postigao ovaj cilj, u program se uključuju mentori koji se tijekom svog pripremanja za ovu ulogu upoznaju s načelima grupne dinamike, pri čemu je iskustvo pokazalo da su u tome uspješniji oni mentori koji su po zanimanju socijalni radnici ili psihoterapeuti, tj. one profesije koje su prenijele neke principe i oblike rada s pojedincem i grupom iz svog stručnog područja u kontekst PUM-O. Upravo ova komponenta

\footnotetext{
${ }^{5}$ Primjerice, u radionici mozaika uz pitanje, kako bi uporabili mozaike, izronila je ideja izrade vrtnih stolova čija je gornja površina mozaik. Za proizvodnju su korištene otpadne drvene role, koje su pravilno obrađene i opremljene mozaikom. Kasnije su prodani u javnoj aukciji u sklopu općinskog praznika.
} 
pristupa radu i temeljni andragoški principi rada (Krajnc, 1994.) s ovom skupinom ranjivih mladih omogućila je da se refleksivna praksa prenese $\mathrm{u}$ uspješan PUM-O knowhow s teorijskim utemeljenjem.

\section{Oblici i načini promicanja grupne kohezije}

Dinamika rada u grupi mladih sudionika PUM-O programa orijentirana je prema strukturiranju dnevnih aktivnosti na način da postoje tri glavna dijela dana, a to su: jutarnja animacija, zajednički ručak i evaluacija dana. Predvidiva struktura i sadržaj koji se kroz njih nudi omogućavaju članovima grupe da se povežu jedni s drugima i podijele svoje obveze ujutro, zatim da zajedno rade ugodne i zabavne aktivnosti, a dan završavaju tako da jedni drugima kažu svoje dojmove o danu i naprave preliminarni plan za sljedeći dan. Poseban naglasak stavlja se na formiranje grupe odmah na početku kada većina sudionika uđe u program, kao i nakon što ga pojedinci napuste i novi članovi uđu u već formiranu grupu. Za formiranje početne skupine potrebno je oko mjesec dana. Za to se vrijeme odvijaju razne društvene igre i aktivnosti učenja koje omogućavaju sudionicima da se upoznaju, procijene zajedničke interese i definiraju zajednička pravila za život u grupi (tzv. »pravila preživljavanja«).

Pravila koja su u programu identificirana od početka odražavaju vrijednosti i obrazovni kontekst u kojem se PUM-O treba kretati. Niti jedna grupa ne može promijeniti ta osnovna pravila, pri čemu se istodobno podrazumijeva da ih poštuju članovi koji se naknadno upišu u program. Kako bi ta pravila pojedinci jasnije doživjeli i prihvatili ona su formulirana u prvom licu jednine (npr. postupam prema svima onako kako bih želio da se drugi ponaša prema meni; dolazim redovito i točno na program, postajem trijezan i ostajem trijezan - alkohol i druge droge nisu dopušteni).
Ova tri osnovna pravila nadopunjuje svaka nova grupa prema svojim prioritetima, a kad ih usvoji konsenzusom, ona se prikazuju na plakatu koji stoji na vidljivom mjestu u prostoru gdje se programske aktivnosti održavaju. Svaka grupa također raspravlja o radnjama i sankcijama koje slijede nakon kršenja pravila. Proces donošenja pravila omogućava pojedincima da prihvate odgovornost za svoje postupke i da preispitaju svoje ponašanje, uzroke i posljedice, kao i moguća kršenja i kako prevladati neprimjereno ponašanje. Kako bi se osigurao nesmetani grupni rad tijekom dugogodišnjeg iskustva rada s grupama i izazova s kojima su se mentori susretali u radu sa sudionicima, formulirana su dodatna pravila koja se primjenjuju u većini PUM-O grupa kao što su, na primjer, nulta tolerancija na nasilje, izražavanje svojih misli naglas, tijekom rada u grupi komunicira se sa članovima u grupi i ne koristi se mobitel.

Poštovanje i nepoštovanje pravila predmet je osobne rasprave mentora s pojedincem kao i grupne rasprave. To se također odnosi na nagrade, razne akcije, kao i sankcije, koje sudionici također oblikuju konsenzusom. Najteža sankcija je isključenje iz PUM-O, ali moguće su i druge mjere - npr. svatko tko češce ne dolazi na program mora donijeti kolačiće ili obaviti neki posao koji nije popularan u grupi (poput pranja posuđa).

Naravno, sankcije su jednako važne kao i nagrade. Na nekim mjestima sudionici svaki tjedan potajno biraju onoga tko je na njih ostavio najbolji dojam, uz pravilo da nitko ne glasa za sebe. Svi bi trebali na glasački listić napisati što je moguće konkretnije zašto za nekoga glasaju. Budući da su to pohvale i priznanja, odabrani sudionik čita naglas svim kolegama za kolegu/ kolegicu u grupi i ujedno se to zapisuje u njegov/njezin portfelj. Takvo prepoznavanje potencijala na osobnoj razini u pojedincu može pobuditi osjećaj važnosti, pozitivne slike o sebi kao i razvoj samopoštovanja i samopouzdanja. 
Promatrajući jedni druge i razmišljajući o međuljudskim odnosima i postupcima pojedinaca, sudionici se međusobno upoznaju i artikuliraju svoje vrijednosti i očekivanja u odnosu na zajednicu. Oni ujedno uspoređuju svoja razmišljanja i osjećanja s razmišljanjima i osjećajima drugih sudionika te stvaraju novu kvalitetu odnosa i u suočavanju s kontradikcijama. Grupa uvijek slavi uspjeh pojedinaca (npr. kada netko položi ispit ili postigne cilj koji je sebi postavio), što je za pojedinca i za grupu osobito važan događaj i kroz koji se nadograđuje grupna kohezija.

Oni također pripremaju i slave iznenađenja na rođendanskim slavljima ili događajima koji su važni za sudionike (npr. rođenje djeteta, zaposlenje itd.).

Timski rad, dobri odnosi s mentorima, identifikacija pojedinca sa skupinom i programom, prema rezultatima svih evaluacija, glavni su čimbenici uspjeha koji polaznici postižu u programu, a vezani su za nastavak ili završetak školovanja, kao i za zaposlenje. Sve su evaluacije pokazale da sudionici programa nisu imali iskustvo ovakvih podržavajućih odnosa u školi, niti su bili uključeni u druge obrazovne programe gdje su se stvarali slični odnosi, a često takve odnose nisu imali niti u obiteljskim i nekim drugim sredinama (Istenič, 2003.). Timski rad i refleksija rada istodobno su osnovni oblici djelovanja mentorske skupine, koja taj princip proširuje na vanjske suradnike različitih institucija (službu za zapošljavanje, centar za socijalnu skrb, liječnike primarne prakse, stručne djelatnike u školama, policiju itd.) koji su također uključeni u rješavanje problema s kojima se sudionici suočavaju. Tijekom rada grupe formira se takozvani Razširjeni strokovni tim (RaST) (Prošireni stručni tim) koji ima mogućnost pronalaska sveobuhvatnih rješenja iz perspektive multidisciplinarne suradnje, istovremeno identificirajući potencijalne sistemske barijere koje otežavaju rad programa ili sprječavaju mladu osobu u nalaženju kvalitetnog rješenja za aktualni problem.

Program PUM-O provodi se $\mathrm{u}$ različitim oblicima kontinuirano 20 godina, a trenutno u različitim gradovima na području Slovenije djeluje 12 grupa. Od 2016. godine u program je uključeno 1376 nezaposlenih mladih u dobi 18-24 godine, većina muških (57\%), pri čemu pojedini član grupe u programu u prosjeku provede između 9 i 12 mjeseci, 6-7 sati dnevno (osim vikenda). Dinamika i sadržaj rada pojedinih grupa malo variraju, ali su - kad se gleda u cijelosti - učinkovite. Drugim riječima, više od $70 \%$ sudionika postiže jedan od ciljeva programa, a to je povratak u neki od oblika obrazovanja ili uđe u svijet rada (njih 25\%). Većina sudionika, između 80 i 95\%, navodi da su na PUM-O-u stekli znanje i vještine koje im omogućuju aktivniji i kreativniji život. Osim toga, sudionici PUM-O-a ističu da su tijekom dolaska u program postali samopouzdaniji, odgovorniji te da su poboljšali životne, radne, obrazovne navike i vještine te da su se sprijateljili i obogatili svoju društvenu mrežu što je jedan od važnijih ciljeva programa (Delloite, 2019.).

\section{ZAKLJUČNA RAZMATRANJA}

Svaka država najčešće upravo u mladima vidi svoju budućnost, međutim NEET populacija nerijetko je nevidljiva u strukturi društva i nedovoljno prisutna u raspravama znanstvene i stručne zajednice. Ovdje se kroz studiju slučaja pokazao primjer programa i iskustvo iz Republike Slovenije u kojem je program PUM-O predstavljen kao mogući odgovor na problem učenika koji su u riziku od ispadanja iz sustava obrazovanja ili već imaju iskustvo ispadanja $\mathrm{i}$ onih koji su dio NEET populacije. Mladi koji su ispali iz sustava obrazovanja zbog niskog školskog uspjeha, ali i zbog nepovoljnih okolnosti u njihovom okruženju na mikroi makrorazini, s jedne strane predstavljaju posebno ranjivu skupinu jer su izloženi 
riziku od socijalne isključenosti, ulasku u društvo s društveno neprihvatljivim oblicima ponašanja i sukobu sa zakonom. S druge strane, njihova niska konkurentnost na tržištu radne snage i dugotrajna nezaposlenost izlaže ih riziku od ulaska u siromaštvo. Uz navedeno, ne treba zanemariti nepovoljne posljedice NEET statusa na psihičko i fizičko zdravlje mladih koji tijekom života nerijetko postaju ovisniji o zdravstvenoj i socijalnoj skrbi te drugim vladinim programima u odnosu na svoje zaposlene vršnjake (Rumberger, 2001., 2011.). Osim toga, populacija »ispadača ima smanjene životne mogućnosti u stvaranju vlastite ekonomske stabilnosti te predstavlja potencijalno velik trošak za državu i društvo, pa se temeljem toga s razlogom ispadanje mladih iz sustava obrazovanja u nekim zemljama promatra kao ozbiljan socijalni problem. Kako bi se smanjio rizik od napuštanja obrazovanja, važno je osigurati preventivne mjere i reforme programa na razini obrazovnog sustava, a ne samo na razini sporadičnih programa organizacija civilnog društva i drugih organizacija kao što je to iskustvo u Hrvatskoj. Ranih 90-ih prošlog stoljeća u Republici Sloveniji obrazovanje mladih odraslih prepoznato je kao prioritetno, razvojno i nacionalno pitanje jer je tadašnji udio nezaposlenih mladih do 25 godina bio $36,3 \%$. Od tada do danas, kada je udio nezaposlenih mladih u odnosu na 1993. daleko niži (oko 5\%), Andragoški centar Slovenije razvio je multidisciplinarni program PUM-O koji se 20 godina kontinuirano bavi na nacionalnoj razini integracijom mladih koji su u riziku od ispadanja iz obrazovanja ili su dio NEET populacije.

Radi se programu koji se temelji na načelima individualnog pristupa i učenja životnih vještina koje mladu odraslu osobu pripremaju na ulazak u društvo iz pozicije njihovog životnog svijeta. U tom kontekstu ih se priprema prije svega na ulazak u neki od oblika obrazovanja i na tržište rada i to kroz multidisciplinaran pristup kako bi se osigurala kvaliteta promjene u životu mlade osobe u cjelini. Upravo u holističkom pristupu ranjivim mladima stoji ključ uspjeha ovog programa, jer se uvažava činjenica da ispadanje iz sustava obrazovanja nije samo pitanje poboljšanja jednog segmenta života mlade osobe, primjerice obrazovnog, nego da se mladoj osobi prilazi kao jedinstvenoj osobi s jedinstvenim potrebama, navikama i ciljevima.

Ovaj program je po svojim rezultatima prepoznat i financiran iz Europskog fonda za socijalni razvoj. U program je od 2016. uključeno preko 1370 mladih, od kojih se preko $70 \%$ uključilo u neki od oblika obrazovanja ili se zaposlilo.

Kompleksna je problematika koja nastaje prije i poslije trenutka ispadanja iz sustava obrazovanja i trenutka ulaska u NEET populaciju. Ti mladi su vrlo često prepušteni osobnim izborima i ograničenim, vlastitim mogućnostima za rješavanje problema te su izloženi riziku od siromaštva i socijalne isključenosti, ali bez obzira na to, vrlo rijetko (neopravdano) ostaju na marginama interesa političke i šire društvene zajednice, umjesto u njezinom centru (Bedeniković, 2017.). Stoga je za vjerovati da iskustvo brojnih mladih članova grupa uključenih u dugogodišnji program PUM-O demantira status njihove isključenosti i nevidljivosti te s razlogom predstavlja primjer dobre prakse zemljama u regiji kako se nositi sa složenošću problema mladih ispalih iz sustava obrazovanja i NEET populacije te provedbom preventivnih mjera na lokalnoj i nacionalnoj razini.

U ovom kontekstu važan je kritički uvid u hrvatsku zbilju glede NEET populacije te istaknuti da se strategije operativnog programa Europske unije trebaju provoditi i u Republici Hrvatskoj. Naime, Operativni program - učinkoviti ljudski potencijali 2014.-2020. jasno navodi da se Hrvatska obvezuje u cijelosti provoditi Plan implementacije Garancije za mlade (PIGzM) do 30 godina starosti te da će ona koristiti 
sredstva Europskog socijalnog fonda (ESF) i provesti Inicijativu za zapošljavanje mladih (IZM) u skladu s mogućnostima na državnoj i lokalnoj razini kako bi se poboljšali uvjeti za uključivanje mladih na tržište rada (Operativni plan - učinkoviti ljudski potencijali 2014.-2020.). Podaci za 2013. godinu, koji su bili početna točka planiranja mjera za razdoblje 2014.-2020., pokazuju da je u Hrvatskoj nezapošljivost mladih do 19 godina bila visokih $35,2 \%$, a NEET populacija je bila zastupljena s 20,9\%, dok je prosjek za EU-a u 2013. bio 15,9\%. Stoga, je navedena obveza u okviru Operativnog programa - učinkoviti ljudski potencijali za Hrvatsku da osigura dostupnost resursa za stjecanje znanja i praktičnih vještina mladih radi usklađivanja s potrebama tržišta rada bila opravdana i dobro planirana. Primjerice, izvedivost PIGzM-a je planirana kroz nekoliko dijelova, a to su prije svega: (a) opsežne reforme i mjere usmjerene sprečavanju ispadanja učenika iz obrazovanja, zatim (b) integracija mladih na tržište rada i mjere poticanja poduzetništva mladih i poslodavaca da ponude obrazovanje uz rad te (c) unaprjeđenje resursa Hrvatskog zavoda za zapošljavanje i drugo (Europska komisija, 2013.).

Prema dostupnim podacima na nacionalnoj razini, ishodi takvih mjera i reformi s konkretnim rezultatima u Hrvatskoj su u većoj mjeri izostali, pri čemu je važno napomenuti da je u PIGzM-u bilo predviđeno osiguravanje sredstava za kreiranje sustava praćenja mladih koji su rano napustili školovanje (oznaka investicijskog prioriteta 8ii) kako bi im se pravovremeno pristupilo i uključilo u dodatne programe obrazovanja za stjecanje svjedodžbe i pripreme za tržište rada.

Osim toga, u Republici Hrvatskoj ispadanje mladih iz sustava obrazovanja na svim razinama, uključujući i akademsku, kao i NEET status još uvijek nisu dobili potrebnu pozornost znanstvene i stručne javnosti, niti su prepoznati kao društveni prioritet i socijalni problem od strane kreatora socijalnih politika. Naime, potrebna su obuhvatnija i longitudinalna istraživanja kojima bi se pratili uzroci i posljedice NEET populacije na području cijele Hrvatske, kako bi se sustavno i prema standardima koje zahtijeva Europska komisija pristupilo kreiranju programa za mlade u riziku od ispadanja i NEET populaciji. Iz iskustva programa PUM-O proizlazi preporuka kreatorima socijalnih politika u Hrvatskoj, da je usmjerenost na socijalno ulaganje kroz konkretne mjere i izvedive planove usmjerene na učinkovitost ljudskog kapitala - a to su u ovom slučaju mladi izvan sustava obrazovanja, izobrazbe i zaposlenja - višestruko isplativo ulaganje kojim socijalna integracija ove populacije doprinosi nadogradnji socijalnog kapitala društva i njegovog ukupnog razvoja.

\section{LITERATURA}

Andragoški center Slovenije. (2010). Evalvacijska študija. Javno veljavni program Projektno učenje za mlajše odrasle (PUM) in Program Temeljno usposabljanje za mentorje (TUM PUM). Ljubljana: Andragoški center Slovenije. Dostupno na https://arhiv.acs.si/dokumenti/Evalvacija_JVP-PUM_TUM_PUM.pdf

Baturina, D., Berc, G., \& Majdak, M. (2014). Nevidljiv problem - stvarni rizik: ispadanje učenika iz srednješkolskog obrazovanja. Revija za socijalnи politiku, 21(1), 43-67. https://doi.org/10.3935/ rsp.v21i1.1161

Baturina, D., Majdak, M., \& Berc, G. (2016). Framing the problem and challenges of dropouts in Croatia: Invisible people around us but not us. In R. Sundby \& A. Heimgartner (Eds.), The Welfare society - an aim for social development (pp. 109-126). Wien : LIT VERLAG GmbH \& Co. KGWien.

Bedeniković, I. (2017). (Ne)zaposlenost mladih i NEET populacija u Hrvatskoj. Mali Levijatan: studentski časopis za politologiju, 4(1), 75-90. https://hrcak.srce.hr/187011

Belton, B. (2010). Radical youth work. Dorset: Russell House Publishing.

Berc, G., Majdak, M., \& Bežovan, G. (2015). Perspektiva stručnih suradnika o ispadanju učenika iz 
srednjih škola kao novom socijalnom problemu. Revija za socijalnu politiku, 21(1), 43-67. https:// doi.org/10.3935/rsp.v22i1.1162

Berc, G., \& Buljevac, M. (2007). Slobodno vrijeme mladih - preventivni aspekti. Dijete i društvo, 9(1), 25-48.

Berger, P., \& Luckmann T. (1989). Družbena konstrukcija realnosti. Ljubljana: Državna založba Slovenije.

Boden, M. A. (2004). Creativity in a nutshell. In M. A. Boden (Ed.), The creative mind: Myths and mechanisms (2nd ed.). London: Routledge.

Čačinovič Vogrinčič, G., Kobal, L., Mešel, N., \& Možina, M. (2005). Vzpostavljanje delovnega odnosa in osebnega stika. Ljubljana: Fakulteta za socialno delo Univerze v Ljubljani.

Čačinovič Vogrinčič, G. (2008). Soustvarjanje v šoli: učenje kot pogovor. Ljubljana: Zavod RS za šolstvo.

Dragoš S., \& Leskošek V. (2003). Družbena neenakost in socialni kapital. Ljubljana: Mirovni inštitut, Inštitut za sodobne družbene in politične študije.

Delloite. (2019). Vrednotenje uspešnosti programa Projektno učenje mlajših odraslih (PUM-O). Vključevanje mladih, ki niso v delovnem razmerju, vizobraževalnem procesu, v procesu nadaljnjega izobraževanja in priprave za vstop na trg dela. Dostupno na https://www.eu-skladi.si/ sl/dokumenti/studije-in-vrednotenja/pumo_koncno-porocilo-final-14032019.pdf

European Parliament. (2011). Reducing early school leaving in the EU: Study. Executive summary. Directorate general for internal policies policy Department B. Available at https://www.europarl.europa.eu/RegData/etudes/etudes/join/2011/460048/IPOL-CULT_ ET\%282011\%29460048\%28SUM01\%29_ EN.pdf

Europska komisija. (2013). Prema socijalnom ulaganju za rast i koheziju - uključujući i provedbu Europskog socijalnog fonda za razdoblje 2014. 2020. Revija za socijalnu politiku, 20(2), 167-190. https://doi.org/10.3935/rsp.v20i2.1152

Eurostat. (2019). Early leavers from education and training. Available at https://ec.europa.eu/eurostat/statistics-explained/index.php?oldid=282391

Flaker, V., Grebenc, V., Rihter, L., Rode, N., Miloševič-Arnold, V., Videmšek, P. Dajčman, B., \& Žagar, A. (2005). Oblikovanje sistema indikatorjev za ugotavljanje potreb ljudi po vrsti in količini posameznih storitev in razvoja novih oblik storitev/pomoči na področju socialnega varstva $v$
Ljubljani (končno poročilo). Ljubljana: Mestna občina Ljubljana in Fakulteta za socialno delo.

Galeša M., Gartner B., \& Palir R. (1972). Vzroki osipa v osnovni šoli: poskus ugotavljanja nekaterih etioloških faktorjev osipa v osnovnih šolah $z$ vidika otroka, družine in učiteljev. Maribor: Založba Obzorja.

Glasser, W. (2002). Nesrečni najstniki: kako naj starši in učitelji poiščejo stiki z njimi. Radovljica: Mca.

Gordon, T. (1983). Trening večje učinkovitosti za učitelje. Ljubljana: Svetovalni center za otroke, mladostnike in starše.

Grebenc, V. (2005). Ocena potreb in raziskovanje lokalnih vednosti kot izhodišče za delovanje $v$ socialnem delu (Doktorska disertacija). Univerza v Ljubljani, Fakulteta za socialno delo.

Guzelj, M. (2012). Travmatični in hujši stresni dogodki udeležencev Programa PUM - Projektnega učenja za mlajše odrasle. Andragoška spoznanja, 18(4), 88-100. Dostupno na https://revije.ff.uni-lj. si/AndragoskaSpoznanja/article/view/496/376

Hackney, H. L. (2012). Savjetovatelj-stručnjak. Jastrebarsko: Naklada Slap.

Hemerijck, A. (2017). The uses of affordable social investment. In A. Hemerijck (Ed.), The uses of social investment (pp.379-412). Oxford: Oxford University Press.

Istenič, S. A. (2003). Evalvacija socialno-integracijske vloge programa Projektno učenje za mlajše odrasle. Ljubljana: Filozofska fakulteta v Ljubljani.

Knavs, S., Bauman, T., Sambolić Beganović, A., Bezić, T., Krajnc, T., \& Malašević, T. (2019). Metodologija spremljanja in preprečevanja zgodnjega opuščanja izobraževanja in usposabljanja. Ljubljana. Center za poklicno izobraževanje in Zavod R Slovenije za šolstvo. Dostupno na https:// www.zrss.si/digitalnaknjiznica/MetodolSpremPreprecev/2/\#zoom=z

Košak, A. (2010). Vpliv revščine in socialne izključenosti na izobraževanje otrok. U V. Leskošek \& B. Petrović Jesenovec (ur.), Od revščine in socialne izključenosti $k$ enakosti, socialni pravičnosti in solidarnosti: zbornik povzetkov 4. kongres socialnega dela. Ljubljana: Fakulteta za socialno delo.

Krajnc, A. (1994). Teoretske osnove in koncept izobraževanja v centrih za mlajše odrasle. Ljubljana: Andragoški center Slovenije.

Kristančić, A. (1995). Svetovanje in komunikacija. Ljubljana: Združenje svetovalnih delavcev Slovenije, AA Inserco. 
Leskošek, V. (2010). Evropska socialna politika v boju proti revščini in socialni izključenosti. U V. Leskošek \& B. Petrović Jesenovec (ur.), Od revščine in socialne izključenosti $k$ enakosti, socialni pravičnosti in solidarnosti: zbornik povzetkov 4. kongres socialnega dela. Ljubljana: Fakulteta za socialno delo.

Magajna L., Pečjak, S., Peklaj, C., Čačinovič Vogrinčič, G., Bregar Golobič, K., Kavkler, M., \& Tanciget, S. (2008). Učne težave v osnovni šoli: problemi, perspektive, priporočila. Ljubljana: Zavod Republike Slovenije za šolstvo.

Matković, T. (2010). Obrazovanje roditelja, materijalni status i rano napuštanje školovanja u Hrvatskoj: trendovi u proteklom desetljeću. Društvena istraživanja, 19(4-5), 643-667. https://hrcak. srce.hr/60108

Mead, G. H. (1934). Mind, self and society. Chicago: Chicago University Press.

Mearns, D., \& Thorne, B. (2007). Savjetovanje usmjereno na osobu. Jastrebarsko: Naklada Slap.

Mrgole, A. (1999). Malopridna mladež, med zaščitniki in preganjalci. Ljubljana: Založba *cf.

Mrgole, A., \& Žalec, N. (1996a). Poročilo o opravljeni 1. fazi evalvacije spremljanja eksperimentalne izvedbe projekta Center za mlajše odrasle v podjetju Mi Amigo v Mengšu (interno gradivo). Ljubljana: Andragoški center Slovenije.

Mrgole, A., \& Žalec, N. (1996b). Poročilo o opravljeni 2. fazi evalvacije spremljanja eksperimentalne izvedbe projekta Center za mlajše odrasle v podjetju Mi Amigo v Mengšu (interno gradivo). Ljubljana: Andragoški center Slovenije.

Mrgole, A., \& Žalec N. (1996c). Poročilo o opravljeni 3. fazi evalvacije spremljanja eksperimentalne izvedbe projekta Center za mlajše odrasle v podjetju Mi Amigo v Mengšu (interno gradivo). Ljubljana: Andragoški center Slovenije.

Miloševič Arnold, V., \& Poštrak, M. (2003). Uvod v socialno delo. Ljubljana: Študentska založba, Knjižna zbirka Scripta.

Obadić, A. (2017). Nezaposlenost mladih i usklađenost obrazovnog sustava s potrebama tržišta rada. Ekonomska misao i praksa, 26(1), 129-150. https://hrcak.srce.hr/183552

Poštrak, M. (1987). Nekaj izhodišč za delo na področju preprečevanja odklonskih pojavov med mladimi na Centru za socialno delo občine Ljubljana-Center. Socialno delo, 26(4), 274-283.

Poštrak, M. (1994). V znamenju trojstev. Socialno delo, 33(4), 325-342. https://www.dlib.si/details/ URN:NBN:SI:DOC-09E1WSHN
Poštrak, M. (1995). Razsežnosti ustvarjalnosti. Socialno delo, 34(1), 37-44. https://www.dlib.si/ details/URN:NBN:SI:DOC-ZW2CI8QD

Poštrak, M. (2001). Antropološki zorni kot. Socialno delo, 40(2-4), 207-229. https://www.dlib.si/details/URN:NBN:SI:doc-NMI6AQXQ

Poštrak, M. (2007a). Uporaba ustvarjalnih pristopov pri delu z otroki in mladostniki. Šolsko svetovalno delo, 12(1-2), 11-17.

Poštrak, M. (2007b). Preventivna funkcija prostega časa. U A. Kristančič (ur.), Svoboda izbire - moj prosti čas (str. 147-165). Ljubljana: A.A. Inserco d.o.o. svetovalna družba.

Poštrak, M. (2011a). Prispevek socialnega dela pri preprečevanju opuščanja šolanja. U P. Javrh (ur.), Obrazi pismenosti. Spoznanja o razvoju pismenosti odraslih (str. 202-218). Ljubljana: Andragoški center Slovenije.

Poštrak, M. (2011b). Refleksija metod dela z mladimi z vidika socialnega dela. U M. Kuhar \& Š. Razpotnik (ur.), Okviri in izzivi mladinskega dela v Sloveniji. Ljubljana: Pedagoška fakulteta.

Poštrak, M. (2015). Koncepti socialnega dela z mladimi. Socialno delo, 54(5), 271-280. https://www. dlib.si/details/URN:NBN:SI:DOC-6I9TMWUA

Poštrak, M. (2019). Socialno delo z ranljivimi mladostniki v njihovem prostem času v Sloveniji v obdobju 1975-1990. Socialno delo, 58(3-4), 125144. https://www.dlib.si/details/URN:NBN:SI:DOC-B4H1MN6H

Rener, T. (2000). Ranljivost, mladi in zasebno okolje. U M. Ule (ur.), Socialna ranljivost mladih. Ljubljana: Ministarstvo za šolstvo in šport, Urad Republike Slovenije za mladino, Založba Aristej.

Rumberger, R. W. (2001). Who drops out of school and why. In A. Beatty, U. Neiser, W. Trent \& J. Heubert (Eds.), Understanding dropouts: Statistics, strategies, and high-stakes testing. Washington, D.C.: National Academy Press.

Rumberger, R. W. (2011). Droping out - Why students drop out of high school and what can be done about it. Cambridge, MA: Harvard University Press.

Simić, S. (2010). Posledice revščine pri otrocih. U V. Leskošek \& B. Petrović Jesenovec (ur.), Od revščine in socialne izključenosti $k$ enakosti, socialni pravičnosti in solidarnosti: zbornik povzetkov 4. kongres socialnega dela. Ljubljana: Fakulteta za socialno delo.

Skaberne, B. (1960). Življenjske razmere delinkventne mladine. Ljubljana: Univerzitetna založba.

Šugman Bohinc L., Rapoša Tajnšek, P., \& Škerjanc, J. (2007). Življenjski svet uporabnika. Ljubljana: Fakulteta za socialno delo. 
Thomas, W. I., \& Znaniecki, F. (1958). Introduction. In The Polish Peasant in Europe and America (Vol. II) (pp. 1831-1914). New York: Dover Publications.

Tomc, G. (1992). Osebna konstrukcija realnosti. Družboslovne razprave, 9(13), 62-78. http:// dk.fdv.uni-lj.si/dr/dr13Tomc.PDF

Tomić, I. (2015). NEETs in Croatia - not in employment, education or training - but where are they? Peer Review on „Targeting NEETs - key ingredients for successful partnership in improving labour market participation". Oslo, 24-25 September 2015, European Commission.

Ule, M., Rener, T., Mencin, M., Čeplak, Tivadar B., \& Vukovič, O. (2000). Socialna ranljivost mladih. Ljubljana: Ministarstvo za šolstvo in šport, Urad Republike Slovenije za mladino. Aristej.

Ule, M. (2003). Kakovost življenja otrok in mladostnikov v Sloveniji, projektna naloga. Ljubljana: Fakulteta za družbene vede.

Ule, M. (2008). Za vedno mladi? Socialna psihologija odraščanja. Ljubljana: Fakulteta za družbene vede.

Uprava za upravljanje operativnim programima Europske unije (2014). Operativni program u okviru cilja - ulaganje za rast i radna mjesta operativni program. Učinkoviti ljudski potencijali 2014.-2020. (prijevod na hrvatski). Dostupno na http://www.esf.hr/wordpress/wp-content/uploads/2015/09/OPULJP-hr-20150709.pdf

Vasta, R., Marshall, M. H., \& Miller, A. S. (2005). Dječja psihologija: moderna znanost. Jastrebarsko: Naklada Slap.
Vodopivec, K. (1959). Priročnikiz metodike socialnega dela. Ljubljana: Šola za socialno delo.

Whyte, B. (2009). Youth justice in practice, making a difference. Bristol: The Policy Press.

Wood J., \& Hine J. (2009). Introduction: The changing context of work with young people. In J. Wood \& J. Hine (Eds.), Work with young people. London: Sage Publications.

Zavod Republike Slovenije za zaposlovanje. (2019). Obvestilo ZRSZ za javnost December 2019. Dostupno na https://www.ess.gov.si/_files/12907/ trg_dela_december_2019.pdf

Žalec, N. (1993). Mlajši odrasli in brezposelnost. U T. Klenovšek Vilič (ur.), Izobraževanje brezposelnih: zbornik II (str. 641-650). Ljubljana: Andragoški center Slovenije.

Žalec, N. (1994). Vzgojnoizobraževalni program centrov za mlajše odrasle. Ljubljana: Andragoški center Slovenije.

Žalec N. (2016). Sodobne andragoške doktrine dela z ranljivimi skupinami odraslih in njihovo vključevanje v družbo. U E. Možina (ur.), Osnovna šola za odrasle. Podoba in poslanstvo (str. 184209). Ljubljana: Andragoški center Slovenije. Dostupno nahttps://pismenost.acs.si/wp-content/ uploads/2017/10/Osnovna_sola_za_odrasle_Podoba_in_poslanstvo.pdf

Žalec, N. (2020). Program Projektno učenje mlajših odraslih (PUM-O). Ljubljana: Andragoški center Slovenije. Dostupno na https://arhiv.acs. si/programi/PUM-O.pdf 


\title{
Summary
}

\section{SOCIAL INTEGRATION OF YOUNG PERSONS AT RISK OF DROPPING OUT OF THE EDUCATION SYSTEM: RESULTS OF THE SLOVENIAN PROGRAMME PROJECT LEARNING FOR YOUNG ADULTS}

\author{
Miloslav Poštrak \\ Faculty of Social Work, University of Ljubljana \\ Ljubljana, Slovenia \\ Natalija Žalec \\ Slovenian Institute of Adult Education (SIAE) \\ Ljubljana, Slovenia \\ Gordana Berc \\ Department of Social Work, Faculty of Law, University of Zagreb \\ Zagreb, Croatia
}

In order to understand the phenomenon of dropping out of the education system, it is important to direct scientific and professional interest on understanding the lifestyle of these young persons from their perspective. The concept of social vulnerability of the youth is useful for that purpose, as it explores risk factors in various life circumstances of young persons, based on which approaches and programmes focused on prevention of dropping out, solving the problems of droputs and unemployed young persons are developed. The programme Project Learning for Young Adults combines both approaches and is based on an individualised, holistic and structured way of working with vulerable young persons. It consists of three levels of project activities: elective, individual and interest based with the aim of developing working habits, team work, self-confidence and career interests in order to reintegrate young adults in the education system and promote their entering the labour market and social inclusion. The programme has been active for 25 years in the Republic of Slovenia and it has included over 1,370 young adults. It has been financed by the European Social Fund.

Key words: vulnerable youth, drop-out, NEET population, project learning for young adults. 